\title{
FRANKENSTEIN'S MORAL RESPONSIBILITY
}

\author{
János KORNAI
}

(Received: 13 October 2019)

Editor's Note: This essay paper of Professor Kornai with an unusually provoking title consists of two parts. Part I is the slightly edited, non-abridged version of his writing published as an oped in The Financial Times (FT) on 11 July 2019, the world's leading global business publication (Kornai 2019a). Subsequently, the full text of this paper was published in the Hungarian weekly magazine Élet és Irodalom (Life and Literature; Kornai 2019b), which in turn generated a number of commenting articles published in the same weekly. Still in the month of July, the original essay was translated into Chinese by a Hong Kong newspaper and into Vietnamese. An influential multilingual Chinese newspaper gave an extensive summary of the FT essay (Street 2019). The latter one, according to our best knowledge, was disseminated only on the internet. Part II is the translated and slightly edited version of Kornai's second article, published in September this year on the same topic (Kornai 2019c). In this second essay he responded to his critiques both in Hungary and world-wide. This piece was published in its original form in Hungarian by the previous mentioned Hungarian weekly. ${ }^{1}$ We, the Editors of Acta Oeconomica, are proud to publish the complete English translation of this second essay first time. We thank for the opportunity given to us by Professor Kornai to publish the Frankenstein-papers in an integrated form, together with all the necessary bibliographic references.

Keywords: Hegemonic power, dictatorship, economic growth, containment

JEL classification indices: F13, F43, F51, H56

1 For precise references see the Reference section of this paper and Professor Kornai's own website, http://www.kornai-janos.hu/Kornai2019-Frankenstein-FinancialTimes.html

János Kornai, Professor of Economics, Emeritus of Harvard University and Corvinus University of Budapest. E-mail: janos.kornai@uni-corvinus.hu 


\section{MY OP-ED ARTICLE IN THE FINANCIAL TIMES}

This piece is written for the intelligentsia, Chinese and non-Chinese, for those who do not evaluate the Chinese changes purely on the basis of individual material well-being, but who consider other aspects as well.

The leaders of modern China have openly announced that turning their country into one of the leading powers of the multi-polar world will not satisfy them. Their aim is for their country to become the hegemonic leader of the globe. The idea is not, of course, to station Chinese soldiers in every country. The means of domination would be different in each country, just as it was in the British Empire of old. There would be some countries literally under military occupation. Elsewhere it would be enough to form governments compliant to Chinese wishes.

Chilling changes are taking place inside China. Deng Xiaoping, the leading figure of the previous period, used rhetoric that he had made up himself. He would never have spoken about giving up the Communist system and establishing a Capitalist one instead. He side-stepped the question. 'It does not matter if the cat is black or white so long as it catches mice.' China's present leader, Xi Jinping has departed radically from Deng's approach. It does matter! China must return to the classical Communist system. The following names appear on the banner: Marx, Engels, Lenin, Stalin, Mao-Zedong and Xi. Stalin and Mao - yes! Deng - no! But the name of Xi, still alive and still in power...

It is not only the form of the personality cult inscribed on the flag that is reminiscent of Stalinist times, but also its actual mechanism. For decades, Deng was the paramount leader; however, his status was not codified in the legal system. This is not enough for the new dictator. He has had a new law passed in March $2018^{2}$, which enables the president of the Chinese People's Republic to remain president until the day of his death. Images depicting $\mathrm{Xi}$ in the traditional robes of the Chinese emperors have appeared in the world press - and there have been no voices of protest from the Chinese side.

2 Editor's note: Two months before this important constitutional change, Professor Kornai gave a major speech partly devoted to China at a two-day Budapest conference organized to celebrate his $90^{\text {th }}$ birthday on 22 February 2018 (Mihalyi 2018). Speaking about the threatening risks he said the following: "The official Chinese ideology is very much influenced by nationalistic ideas. Now, if China were the only nationalist power in the world, then one can think about isolation. But that is not the case. There are other giants, which are also nationalist. There is the USA, where the President is announcing 'America first'. Not the globe first, not the international community, not the future of the international community first, but America first. And then we have Russia, where the leadership again is explicitly and emphatically nationalistic." (Kornai 2018: 61-62) 
$\mathrm{Xi}$ is re-forming the Communist party and turning it into the main holder of power. In every sizeable institution and company a Communist party organisation must be established, which is independent of the management of that institution or company. These are not just independent: in certain areas of legal authority they can overrule the management. Readers may recall the relationship between the commissar chosen by the party and the military commander appointed by the generals in the years of the civil war, following the revolution in 1917. If he was dissatisfied with the commander, the commissar could oust him.

Mass re-nationalisation has not been carried out. A large part of output is still produced in non-state owned enterprises. However, the party control described above functions in the corporate sector as well: in case of disagreement the party secretary has the final word.

Show trials are going on, marked by the characteristics of modern China. Anybody can be taken to court for corruption, either because they really are corrupt, or because corruption charges can somehow be pinned on them. Prisoners are being tortured again. While during the Deng period the death sentence was not really used - instead, rather less harsh sentences were handed down, such as lifelong house arrest (especially for fallen leaders) -, now the death sentence has become common again.

Thanks to the internet, the central government has not managed to suppress the freedom of speech and of the press completely. Some achievements of the Deng period have survived, so political discussions can take place in small groups of individuals, but the network of prohibitions is thickening, and the risks associated with the expression of criticism are growing.

So in the country which is the contemporary version of the frightening past the Communist system sooner or later would become the hegemonic master of the world? A terrifying prospect.

Are we not also responsible for this nightmare; the Western intellectuals who have not only watched China's transformation with approval, but have actively contributed to these changes? Frankenstein, Mary Shelley's vision published in 1818 (Shelley 1818), has appeared in a hundred different literary forms, in films, plays and cartoons. Frankenstein is an experimenting scientist who brings a dead body to life using a technique which, in those days, was considered modern technology: the electric shock. The resurrected creature becomes a monster who starts committing murders and other dreadful deeds.

We, Western intellectuals dealing with China, are - perhaps with a few exceptions - the Frankensteins of our time. Many of us already bear moral responsibility for not protesting against the resurrection of the monster. And there are those whose responsibility goes much further, because they have taken on an active role as advisors. I include myself here: the Chinese reformers considered my book 
'Economics of Shortage' (Kornai 1980) as essential reading. I travelled to China on a number of occasions; I took part in the 'Bashan conference' in 1985. The organizers invited seven Western economists, and also leading policy-makers of China. All of us were put on a luxurious boat quietly floating on the Yangtze River. That is the reason why this rather unique gathering is also named the 'Boat Conference'. Each invited economist got a full day for presenting his ideas on China's reform, answering questions, disputing various opinions. I lectured on how the country should be transformed into a market economy. In the present piece where, in anguish, I raise the question of my moral responsibility, it will not be considered a boast if I state that in those 10-20 years, when market reforms were taking off, my written and spoken ideas had powerful effects. Naturally, I was not alone. Many other Western intellectuals, among them numerous China experts, gave similar advice. We gathered at conferences, where we shared our thoughts with each other. Many views clashed, but what we all agreed on was that new life would be brought to China, which had frozen under Mao, by the electric shock therapy of marketization and private property. All of us who advocated this plan were Frankensteins - and now, behold: the fearsome monster is here.

I include our Chinese disciples on the list $^{3}$, who then were still students or already professors advocating the power of marketization and private property themselves. With good reason, because these measures really accelerated growth. And at the same time it caused damage, the best intentions notwithstanding, because the giant that has arisen turns against them too, harassing them, hindering them from spreading their ideas. The experimenting scientist himself watches what is happening with dismay.

Having read the essays warning of the threatening dangers many people ask: "Well, so what should we do now?" Even if I will not act as an advisor, I will venture to issue a few warnings. It is not possible to resist the Chinese expansion drive by focusing on the raise of customs duties only. China is advancing literally on all fronts, by developing its armed forces, using state-of-the-art devices which are put into the hands of the world's biggest army. Also, China is quick in utilising or even innovating the means of the virtual, high-tech world, with which they can influence the political and economic processes of their rivals.

Numerous investors worldwide are enthusiastic about investing in China. In their eyes, a stable dictatorship is a more secure environment for a capitalist company than a wobbly democracy. Luckily there are other capitalists who have an active conscience, and are motivated by a sense of human solidarity. There is no problem with some toy or bathroom accessory being made in a Chinese fac-

Editor's note: One of these disciples has recently published an important paper in this journal on the pitfalls of the now recentralising Chinese bureaucracy (Xu 2019). 
tory, but one should think twice before assisting China in manufacturing devices which can be used in physical or digital warfare. The gates of universities should be open to Chinese students - except those gates which encourage the manufacture of the arsenal of modern warfare.

Decades ago, in the context of the threatening US-Soviet confrontations, a high-ranking American diplomat, George Kennan summarised what should be done, using the expression 'containment' (Kennan 1947). Thus far and no further! Or more precisely: no further in this direction! What has happened already cannot be undone. But here we must stop, and we must take far more care to avoid carrying on in the role of Frankenstein.

\section{RESPONSE TO THE FEEDBACK}

My article Frankenstein's Moral Responsibility was published in the middle of 2019, first in English (Kornai 2019a), then in Hungarian (Kornai 2019b). I cannot judge the strength of the reaction that it aroused overall, but I would like to answer the feedback that has reached me, either because the author published it in some form or another, or because it was communicated to me in a conversation or in a letter.

As could be expected, the reception was not uniform: it varied widely, from total agreement to sharp refusal. Different topics also elicited different kinds of feedback.

My essay might imply that the main explanation of the very rapid growth of China's economy was caused by marketization and changes in ownership relations. As such, this does not stand up. If the reader interpreted the essay in this way, it is the author's fault: I did not make it clear that this is only one, not the only, explanation of the rapid growth. Among the explanations, an extreme version of the Stalinist type of extensive growth is of outstanding importance. The proportion of GDP used for capital investment is very high, while the proportion used for consumption is relatively low. There was a period when the proportion allocated to consumption shrank to half of the GDP. This is unheard-of in the recent economic history all over the world. And China could do it all without this tumultuous growth being impeded by the lack of manpower. The population poured into the towns where new industries sprang up. True, I should have emphasized this point.

Many critics claimed that China would have done the same - namely allowing the transformation of market conditions, the free adjustment of demand, supply and prices to each other, as well as the emergence of new small enterprises on a large scale - without the encouragement of Western advisors. Unfortunately, Icannot prove my own contention that encouragement from Western advisors did 
have an effect, though I would add that my opponents in this debate cannot support their refutation of this with what we call scientific methods either. In such cases, the method of verification that economists most often employ is that of multivariate regression analysis. We have at our disposal time series referring to numerous countries going back a very long time, which makes multivariate regression analyses possible. These statistical approaches offer a good reference point for the consideration of a variety of problems, for example for the regulatory approval of new medications. However, they do not enable us to draw any definite conclusions about China, this historically unique, enormous country. All I can say is that what I claimed in my original essay was based on a conjecture; it was not a statement based on scientific evidence. Naturally, the same can be said of the claims made by my opponents.

Some stated critically that other Westerners gave similar advice, so why do I presume that mine had a stronger influence? My essay was an exercise in selfcriticism, psychologically it is understandable that I did not wish to use my selftormenting contemplations to boast. Yes, my influence on Chinese experts was stronger than that of other advisors, even before the famous Basham conference ${ }^{4}$. There was a group of Chinese leaders who did not express any opinion just listened to the talks of altogether seven Western experts. For an unbiased witness I can refer to a PhD dissertation, the work of Julian Gewirtz, which was written at Harvard University, and was also published in book form (Gewirtz 2017).

In the responses I received so far, there was no agreement on whether today's China is not only a monster, but also more frightening than the other behemoths. I stand by my opinion. China is the most dangerous, because it wants to restore the situation when there was only one hegemonic state. In a given historical period either there are several separate world powers existing side by side, or there is one, a single one which plays the role of the hegemon.

To clarify the concept of hegemon, I would recall the story of the 1962 missile crisis. Khrushchev, leader of the Soviet Union at the time, deployed missiles in Cuba, which, if the order to launch had been given, would have reached American cities. The world had reached the threshold of an American-Soviet conflict, which would have meant a world war. After extremely tense negotiations Khrushchev backed off. He thus de facto acknowledged the hegemony of the USA.

So far, China has not had the opportunity of such a test of strength. We have to rely on our imagination. For the sake of argument, let us play with the following chain of events. China sends numerous war ships (carrying huge numbers of tanks and infantry), accompanied by many planes, to Taiwan. It openly de-

4 Basham, as I already mentioned in Part I, was the name of the tourist vessel which hosted our conference. 
clares that it has the right to take over Taiwan; after all, it has never recognised it as an independent state, but has always considered it as part of China. And let us now ask the critical question: would the USA risk going beyond protesting through diplomatic channels, and only sending a few war ships to demonstrate its strength? Would it actually employ its full military might to prevent the conquest of Taiwan? Or would it not dare to defend Taiwan by employing real military power? In the latter case, it would de facto acknowledge China's hegemony.

Some of my critics are of the opinion that I overestimate China's military strength, as the technology available to the US military far surpasses that of China's armed forces. True; however, this bears no relevance to the dangers I described. Let us return to the hypothetical Chinese attack on Taiwan mentioned above. The success of such action would not depend on the technological level of the weapons involved, but on their quantity. China would really be able to conquer Taiwan, simply by flooding it with tanks, and even with infantry.

Let us move on to the ethical aspects of my article. The majority of feedback reaching me concerned China's affairs. It discusses whether my statements about China are correct or not. For me, as the author, this constitutes a failure. I hoped that the reader would understand: the ethical aspects do not only concern China. Even the title of the essay refers to this: Frankenstein's moral responsibility. As is well known, China does not figure in the Frankenstein story at all. The title was intended to make the reader aware of a universal dilemma: the person who brought the monster to life is responsible for its behaviour.

There were voices which recognised that it was a notable achievement to accept responsibility honestly for a problem in whose creation I had played a part. It pains me that only two or three commentators gave me this acknowledgement. In the sample of feedback that reached me, many people considered this as exaggerated self-reproach; indeed, there were some who labelled it unjustified selfreproach.

A great short story by the Czech writer Karel Čapek comes to my mind (Čapek 1969). A criminal dies and arrives at the gates of the afterlife. He expects God to sit in judgement upon him there. The hearing takes place, there is only one witness. Then comes a pause: the jury withdraws to consider its verdict. In the meantime, the accused and the witness engage in conversation. It turns out that God was the witness; he is totally credible, since he has seen everything precisely. God explains this: even in the afterlife, humans pass judgement over humans. In the short story, the jury consists of people who worked as professional magistrates on earth.

In my essay, I attempted to take on all the roles at the same time: I prosecuted myself as an attorney, I acted (rather feebly) as my own defence counsel, and I passed pitiless judgement over myself as magistrate. 
The situation is somewhat different with commentators. Many undertook the role of defender. They bring up many excuses.

What was my aim with my bad advice? Was I specifically striving to harm China? Surely, not. This is almost enough for acquittal.

Another angle worth considering: maybe I did not possess enough information to consider beforehand whether I was doing any harm with my advice. This makes it into a case of criminal negligence. How could János Kornai know at that time where it would lead if his advice was taken?

I do not take this argument seriously even today. I had been a professional researcher of communist systems for decades. I should have known that a communist dictatorship is capable of anything. When I took part at the Basham conference, decades had passed since the Hungarian Revolution of 1956 and the terrible retribution that followed it.

When I was giving advice without hesitation it was based on two theories, which circulated widely among China experts. One of these was: let the economic reform come first; it will quickly create the right conditions for political reform. The other theory was that successful, gradual economic growth will be accompanied by the organic development of democracy. The second one was the path followed by history in numerous Western European countries, and we thought it would surely happen in China, too. However, just because this chain of cause and effect happened successfully in various Western European countries does not mean that it has to happen in the same, or even in a similar, way in China.

Some people understood that I consider myself to be the guilty No. 1, or at least one of the main culprits. This is a complete misunderstanding. The main culprits are obviously those Chinese communist leaders whose policy has finally formed China's present system. The paramount leader, the 20 or 30 deputy heads surrounding him who supported the supreme leader, and all those Western experts who did not speak out about the danger. On me only a small portion of guilt falls, but it is enough to burden my conscience.

I had many defenders. However, to be honest, my main aim was not to place myself before the moral court of the public. What I strove to achieve was for my readers to ask themselves: is my political conscience clear? Not in the matter of China, but in any important issues they have been involved with. Let me quote Socrates: an unexamined life is not worth living (Plato 1966: 38a). Such an examination does not ease the conscience of the one who decides to undergo it. It has not become easier for me either since I wrote the essay. And still I feel: I had to do it.

Let me make a point here: the words of Socrates can be interpreted as the statement of an intellectual aristocrat who is proud of his knowledge; the life of people to whom it never occurred to consider their past self-critically was not 
worth living. This has prompted a great deal of debate among professional philosophers. I have read one of them, the book by Robert Nozick (1990), one of the great philosophers of our time; his take on the problem is different from that of Socrates himself.

I have never for a moment considered myself a philosopher; this discipline has its own professional experts. I only gathered enough courage to outline my own views in a few lines, while literature enough to fill a library has been published on the question.

My original essay did not only deal with ethical problems, but it also took a stance about practical issues. I consider Trump's initiative of imposing a general import tariff on Chinese products a mistake. It affects China's economy negatively, but also puts extra burden on the shoulders of the American household and entrepreneurial sectors, which from now on will be reluctant to buy cheap Chinese products. Instead, targeted restrictions would be needed, the main instrument of which is not a general protective tariff. Instead, restrictions strongly forbidding any relationship which could promote the development of China's military potential would be needed. Such harmful and dangerous relationships can emerge in the sphere of investment, foreign trade, higher education and research. Great harm could befall the democratic world in all forms of conflict, both in traditional warfare and in cyber-war and espionage, fought with the most state-of-the-art methods. Being a layman, I only talk about the general aims of targeted restrictions; experts in the field must put together a detailed system of prohibitions.

My essay concluded with 'containment', recommended by George Kennan (1947), when he advised the forceful maintenance of existing borders to resist Soviet expansion in the first years of the Cold War. This part of the essay triggered neither agreement nor objections. ${ }^{5}$ Most readers most likely thought that they already knew about it. However, my feeling is that it is not much discussed, as the media, commentators and politicians talking to the public do not utter a word about targeted actions; rather, they focus public attention on the tariff war.

In summary, my impression is that my essay has not triggered the response I had hoped for. The fact that I now return to the points raised in the feedback proves that I have not given up the fight.

5 Editor's note: Since then the situation has changed profoundly. In the September 2019 issue of Foreign Affairs, the leading US magazine for analysis and debate of foreign policy, five lengthy papers were devoted to the assessment of President Xi' policies and the risks emanating from them. One of these papers - Westad (2019) - was entirely built upon the relevance of the 1947 Kennan paper exactly in line with Professor Kornai's argumentation above. 


\section{REFERENCES}

Čapek, K. (1969): Az utolsó ítélet (The Last Judgement). In: Betörők, bírák, büvészek és társaik (Burglars, Judges, Conjurers and Their Companion). Translated to Hungarian by András Zádor. Budapest: Európa Könyvkiadó, pp. 132-136.

Gewirtz, J. (2017): Unlikely Partners: Chinese Reformers, Western Economists, and the Making of Global China. Cambridge, MA: Harvard University Press.

Kennan, G. F. (Mr. X.) (1947): The Sources of Soviet Conduct. Foreign Affairs, vol. 25, pp. 566582.

Kornai, J. (1980): Economics of Shortage. Vol. A-B. Amsterdam: North-Holland.

Kornai, J. (2018): About the Value of Democracy and Other Challenging Research Topics. Transcript of the closing speech of Kornai at the 2-day conference organized on the occasion of his 90th birthday at the Corvinus University of Budapest on 22 February, Köz-Gazdaság, 2: 59-63. http://unipub.lib.uni-corvinus.hu/3565/1/2018_KG_2_Janos_Kornai_About_the_value.pdf

Kornai, J. (2019a): Economists Share Blame for China's 'Monstrous' Turn: Western Intellectuals Must Now Seek to Contain Beijing. Financial Times, online on July 10, in print on July 11: 11.

Kornai, J. (2019b): Frankenstein erkölcsi felelőssége. Gondolatok Kína piaci reformjáról. (Frankenstein's Moral Responsibility. Thoughts about Market Reform in China). Élet és Irodalom, LXIII July 19: 5.

Kornai, J. (2019c): Frankenstein erkölcsi felelőssége. Válasz a visszhangra (Frankenstein’s Moral Responsibility. Response to the Feedback). Élet és Irodalom, LXIII (38), September 20.

Mihalyi, P. (2018) János Kornai turns 90 on January 21. Editor's Preface. Acta Oeconomica, 68(Special Issue): $3-8$.

Nozick, R. (1990): Examined Life: Philosophical Meditations. New York: Simon \& Schuster.

Plato (1966): Plato in Twelve Volumes. Vol. 1, translated by H. N. Fowler. Cambridge, MA: Harvard University Press.

Shelley, M. W. (1818): Frankenstein. London: Lackington, Hughes, Harding, Mavor, \& Jones.

Street, C. (2019): Western Economists: China Experiment Now Frankenstein's Monster. The Epoch Times, July 15.

Westad, O. A. (2019): The Sources of Chinese Conduct. Are Washington and Beijing Fighting a New Cold War? Foreign Affairs, 98(5): 86-95.

Xu, Ch. (2019): The Pitfalls of a Centralized Bureaucracy. Acta Oeconomica, 69(1): 1-16.

Open Access. This is an open-access article distributed under the terms of the Creative Commons Attribution 4.0 International License (https://creativecommons.org/licenses/ by/4.0), which permits unrestricted use, distribution, and reproduction in any medium, provided the original author and source are credited, a link to the CC License is provided, and changes - if any - are indicated. (SID_1) 